Acta Horticulturae et Regiotecturae 2

Nitra, Slovaca Universitas Agriculturae Nitriae, 2018, pp. 30-35

\title{
MYCORRHIZA AND STRESS TOLERANCE OF VEGETABLES: A REVIEW
}

\author{
Samuel ADAMEC ${ }^{*}$, Alena ANDREJIOVÁ \\ Slovak University of Agriculture in Nitra, Slovak Republic
}

\begin{abstract}
From year to year, the world growing area is being more poluted with heavy metals or excessive salt level and exposed to lack of moisture or avaiable nutrients in the soil. This resulting in a loss of agricultural land where vegetables were grown in the past. The producers must also fight with more resistant and new species or strains of soil pathogens, while chemical protection is not always the most suitable solution for human health and the environment. Our review focuses on the great importance of using arbuscular mycorrhizal fungi to alleviate abiotic and biotic stress, taking into account the use in vegetable production. The review is gradually focusing on individual stressors and defines the mechanisms of mycorrhizal fungi that contribute to the sustainable agriculture even under severe stress conditions.
\end{abstract}

Keywords: mycorrhizal fungi, abiotic stress, biotic stress, vegetables

Mycorrhizal symbiosis, a mutually beneficial relationship between soil fungi and plant roots, is one of the first symbiotic relationships that have evolved on our planet. Already more than fifty years ago, Balis in the New Zealand observed positive impact of mycorrhizae on the phosphorus uptake by the host plant. By observing nature around us, but also by controlled experiments, humans have gradually discovered many other benefits that mycorrhizal fungi bring to host plants. Nevertheless, even today we do not know everything about mycorrhiza. Mycorrhizal symbiosis is an extremely complicated relationship, and a lot of effort has to be made to obtain any new information about its functioning. Especially in Turkey, Italy, India and other Asian countries many scientists have been dealing with mycorrhiza and from year to year, increasing number of scientific papers describe the newly found positive effects it has on plants, or the possibility of its use in agriculture and forestry. Mycorrhizal symbiosis is widespread in nature. If we grow a plant in the absence of mycorrhizal fungi, we do something unnatural, something that is unusual in nature. Majority of plants host mycorrhizal fungi on their roots and finding a plant without them is quite difficult. As we cross the countryside, we constantly step on an invisible underground network of fine fibers (hyphae) of mycorrhizal fungi (Gryndler et al., 2004; Koide and Mosse, 2004). However, in Slovakia, mycorrhiza has not yet become known to the growers as much as it deserves. We believe that this review could also help to make this issue more visible and help to share the latest knowledge about the use of mycorrhizal fungi in horticulture.

For vegetable growers, the most important type of mycorrhiza is arbuscular mycorrhizal symbiosis. Arbuscular mycorrhiza (AM) is the most ancient and widespread form.
Paleobotanical and molecular sequence data suggest that the first land plants formed associations with Glomalean fungi from the Glomeromycota about 460 million years ago. This is estimated to be some $300-400$ million years before the appearance of root nodule symbioses with nitrogen-fixing bacteria (Finlay, 2008). Intercellular and intracellular fungal filaments are characteristic - hyphae and especially specific intracellular structures - arbuscules (these are tree-like structures that allow the interchange of nutrients between the fungus and the plant) and vesicles (cams that store the stock for both the fungi and the plant) (Figure 1). According to these unique structures, this type of endomycorrhiza is also called vesicular-arbuscular mycorrhiza (VAM). Fungal organisms that are involved in this symbiosis live exclusively in connection with plants and do not form any visible structures to the naked eye. These fungi are also referred to as biotrophic symbionts that are unable to exist without their plant partner and cannot be artificially cultivated in vitro (Kavková, 2014).

The infection of the roots occurs through the inoculum which is present in the soil as spores or mycelium. After the first mycorrhizal infection, AM fungi are massively spreading in root cells and colonize surrounding cells, especially in deeper layers of the root cortex and intercellular spaces. From the surrounding soil, it leads to further infections of root cells and the connection between extramatricular mycelium, and mycelium inside the cells is multiplied (Mejstř́k, 1988).

Genus Glomus is the largest genera of AM fungi, with 85 described species. This includes the important species such as G. claroideum, G. etunicatum, G. mosseae (e.g. Funneliformis mosseae), G. viscosum, G. fasciculatum or the most important and used Rhizophagus irregularis (previously 


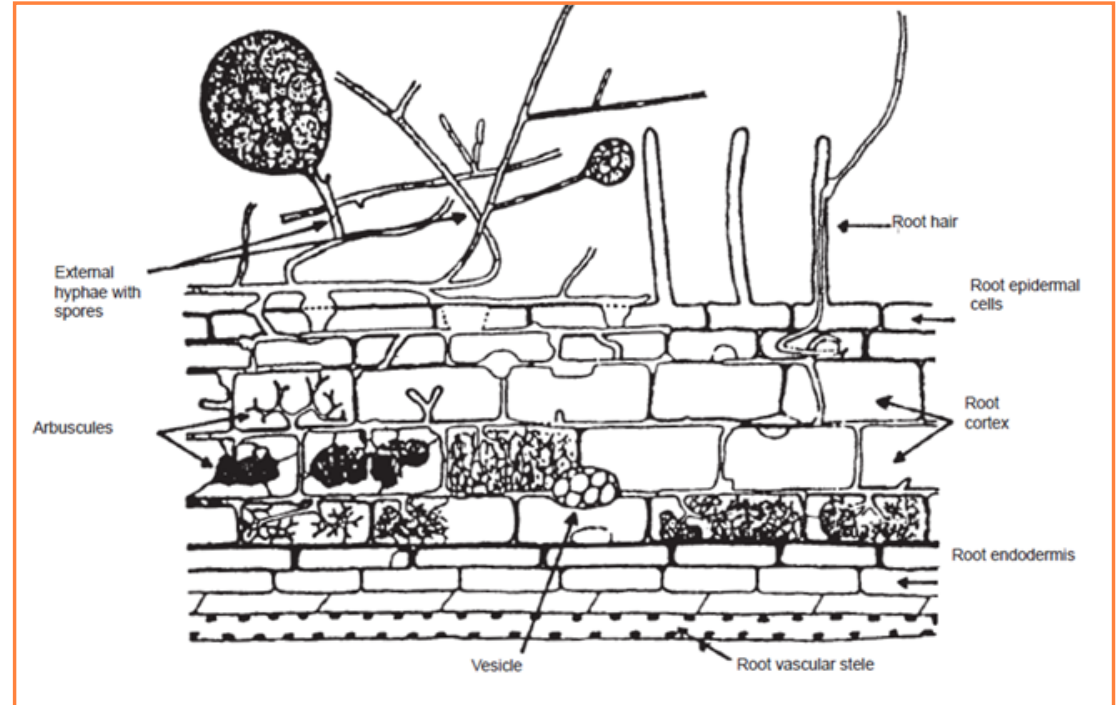

Figure 1 Diagram of a root colonized by AM fungi showing the diagnostic features of the fungi

Source: Habte, 2000

known as Glomus intraradices), which is also mentioned in several contexts of this article. Rhizophagus irregularis (Glomeromycota) has been found in different ecosystems around the world, including temperate and tropical regions. It is also the first AM fungi from which the genome was sequenced (Tisserant et al., 2012).

AM fungi are able to create a symbiosis with most vegetables including major crops of different families, such as: Alliaceae, Apiaceae, Asteraceae, Fabaceae and Solanaceae (Baum et al., 2015). In the cultivation of vegetables and other crops with AM fungi, it is also recommended in crop rotation to rotate only crops that are also able to form mycorrhizal symbiosis, which also applies to inter-crops. It is unsuitable to use fungicides for mycorrhizal cultivation, as along with pathogenic fungi we can kill mycorrhizal ones. Too frequent application of herbicides and insecticides is also unsuitable (Elbon and Whalen, 2015).

\section{The importance of mycorrhizal fungi against abiotic factors}

\section{Drought}

Drought is one of the major constraints on plant productivity worldwide and is expected to increase with climatic changes. Several ecophysiological studies have demonstrated that AM symbiosis is a key component in helping plants to cope with water stress and in increasing drought resistance (Figure 2). The alleviating effect of AM symbiosis in response to drought generally relies on the positive effects of AM fungi on the uptake and transport of water and on an improved uptake of nutrients, especially of available soil phosphorus $(P)$ and other immobile mineral nutrients, resulting in the hydration of plant tissues, a sustainable physiology and a clear promotion of growth (Rapparini and Peñuelas, 2014).

An increased root length and density or an altered root system morphology (Fig. 3), as enhancing soil exploration and water extraction, have been hypothesized as potential mechanisms for the improved drought resistance of mycorrhized plants. Enhancement of plant stomatal control or root water uptake by mycorrhizal hyphae, as well as turgor maintenance by osmotic adjustment, have been documented. At the levels of both leaves and roots, the osmotic stress usually caused by drought is counteracted by mycorrhizal plants through biochemical changes that mostly include increased biosynthesis of metabolites (mainly proline and sugars) that act as osmolytes. These compounds contribute to the lowering of the osmotic potential, and in turn, of the leaf water potential. These lower potentials allow the plants to maintain high organ hydration and turgor that sustain overall cell physiological activity, mainly related to the photosynthetic machinery. AM plants withstand drought-induced oxidative stress with increasing the activities of antioxidant enzymes. Mycorrhizal fungi also affect the hydraulic conductivity and gas exchange in the root and leaves. Molecular mechanisms activated by AM symbiosis to counteract drought include gene activation of functional proteins, such as the membrane transporter aquaporins (Bethlenfalvay and Linderman, 1992; Candido et al., 2015; Rapparini and Peñuelas, 2014). Rob (1985) also stated that mycorrhizal plants restored their normal functions after a temporary shortage of water

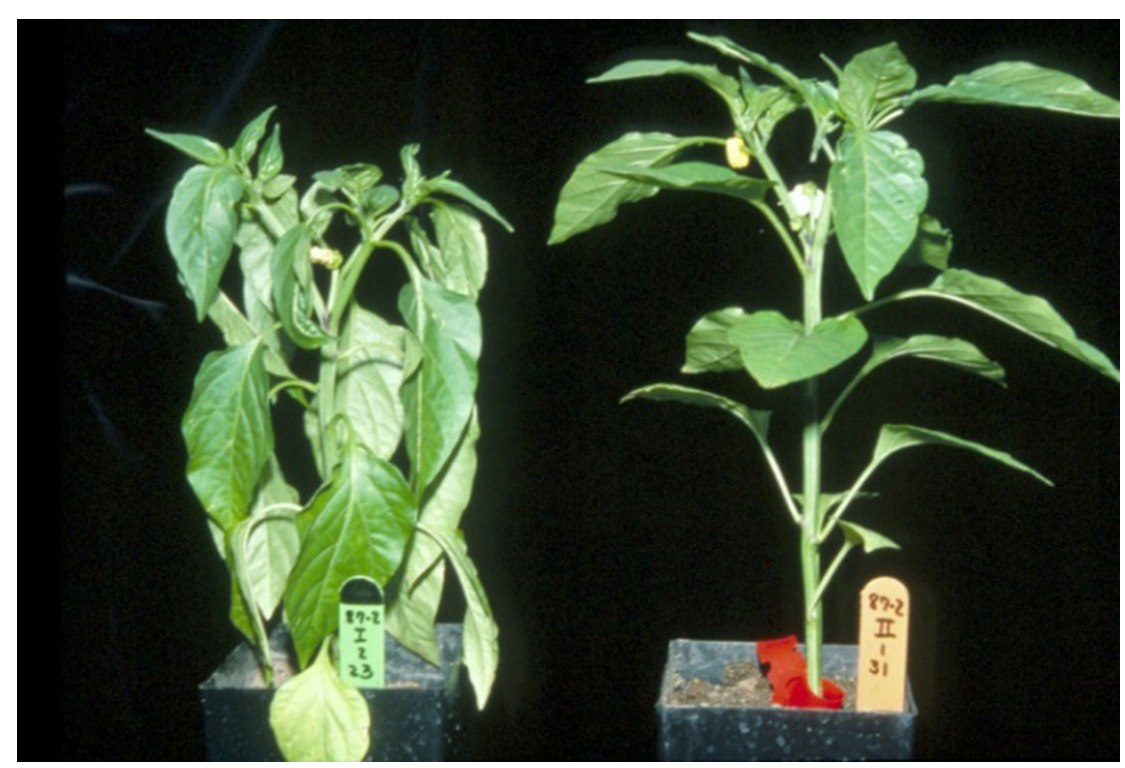

Figure 2 Pepper plant with AM fungi on the right and non-AM plant on the left Source: Davies, 2016 


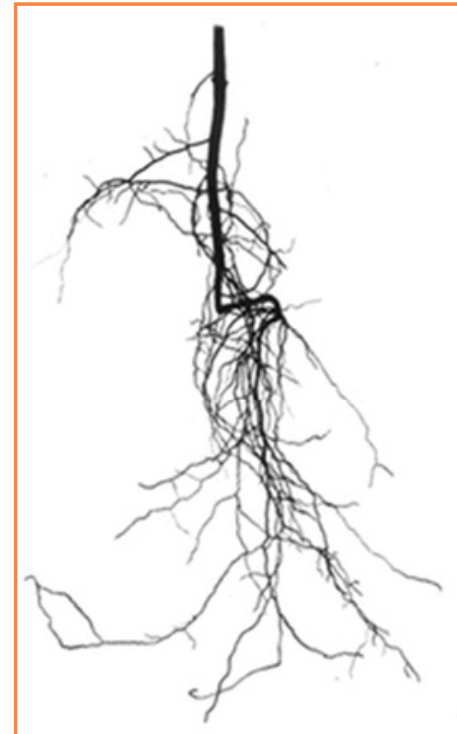

drought stress - Funneliformis mosseae

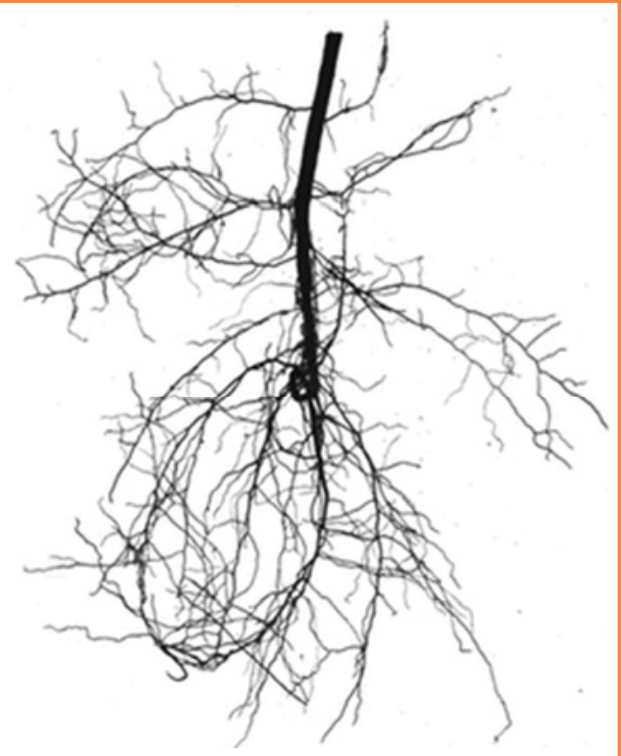

drought stress + Funneliformis mosseae

Figure 3 Root inoculated with Funneliformis mosseae under drought stress Source: Wu and Zou, 2017

faster than non-mycorrhizal plants. He assumed that the cause was to reduce the resistance on the water transport pathways.

In addition, AM symbiosis can increase the resistance of plants to drought through secondary actions such as the improvement of soil structural stability that in turn increases the retention of soil water. For example, Tauschke et al. (2015) indicated a positive effect on corn, soybeans, onions or lettuce in their study. Hazzoumi et al. (2015), during their research, reported that basal plants inoculated with $G$. intraradices showed better growth than noninoculated during drought stress, while mycorrhiza improved growth of the overground parts of the plant by $51 \%$ and the root part by up to $130 \%$.

\section{Soil salinity}

To deal with saline soils and minimize crop loss, scientists have searched for new salt-tolerant crops or varieties or breaded salt-tolerant cultivars through breeding etc. However, biological processes such as mycorrhizal application to alleviate salt stress could be a better option. AM fungi have been reported to promote plant growth and salinity tolerance by many researchers. It is found to vary with the isolates of fungus and species of plants (Heikham, Rupam and Bhoopander, 2009). Several authors reported (Heikham,
Rupam and Bhoopander, 2009; Baum et al., 2015) that mycorrhizal fungi promote salinity tolerance by employing various mechanisms, such as enhancing nutrient acquisition, producing plant growth hormones, improving rhizospheric and soil conditions, altering the molecular (changes in gene expression and ultrastructural changes), biochemical (accumulation of antioxidants, proline, betaine or soluble carbohydrates) and physiological (photosynthetic activity, relative permeability, water relation or nodulation and nitrogen fixation in vegetables) properties of the host. In addition, AM fungi can improve host physiological processes like water absorption capacity of plants by increasing root hydraulic conductivity and favourably adjusting the osmotic balance and composition of carbohydrates. This may lead to increased plant growth and subsequent dilution of toxic ion effect. At experiments on soybean, bean, and vigna plants, mycorrhizal plants have been found to have a significantly increased accumulation of proline, non-toxic and protective osmolyte, which helps the plant maintain osmotic balance at low water potentials and acts as a reservoir of energy and nitrogen during salt stress. At higher salinity levels, the glycine betaine (quaternary ammonium compound) content in AM plants was about twice as large as in non-AM plants. AM ameliorated the negative influence of salinity stress which enhanced the activity of antioxidant enzymes such as catalase (CAT) and peroxidase (POD). What is more, AM inoculation further improved their activity, thus strengthening the defense system of plants (Heikham, Rupam and Bhoopander, 2009; Mohsen and AbdelRahman, 2016; El-Sarkassy, Ibrahim and Desoky, 2017). A good example would be Al-Karaki (2013), who observed greater size and weight of the root dry matter during salt stress, as well as the overall increased yield of tomato fruits in terms of both weight and quantity, for mycorrhiza plants, as in any variety of non-mycorrhiza tomato plants. Heikham, Rupam and Bhoopander (2009) reported improved growth, yield, water status, nutrient content and fruit quality of the pumpkin plant colonized with the species of the genus Glomus sp under salt stress. El-Sarkassy Ibrahim and Desoky (2017) also mentioned that application of mycorrhiza gave positive effect and enhanced all growth parameters of pepper plant at all levels of salt stress (2,000 ppm and 4,000 ppm), thus acting as a growth stimulant.

\section{Heavy metals}

Hildebrandt, Regvar and Bothe (2007) indicated that in the vegetable production, particularly Glomus intraradices isolates proved to be successful. Under conditions of optimal root infection they can provide protection against several heavy metals in the soil for many plant species. But until recently, it could not have been distinguished, whether elements in the inner root parenchyma cells were deposited in the fungal cells, plant cells or both types. Very recent results obtained from electron-dispersive X-ray spectrometry (EDXA) showed that $\mathrm{Zn}, \mathrm{Cu}$ and $\mathrm{Cd}$ accumulated in the cell wall and in electron-dense granules in the cytoplasm of the fungi while their cytoplasm itself was essentially free of these elements. Other studies showed that glomalin produced by AM fungi and in large quantities released into the soil is also capable of immobilizing a significant amount of metal (Seguel, 2014). Increased tolerance to $\mathrm{Cd}$ stress was observed in carrots with inoculated AM fungi of 


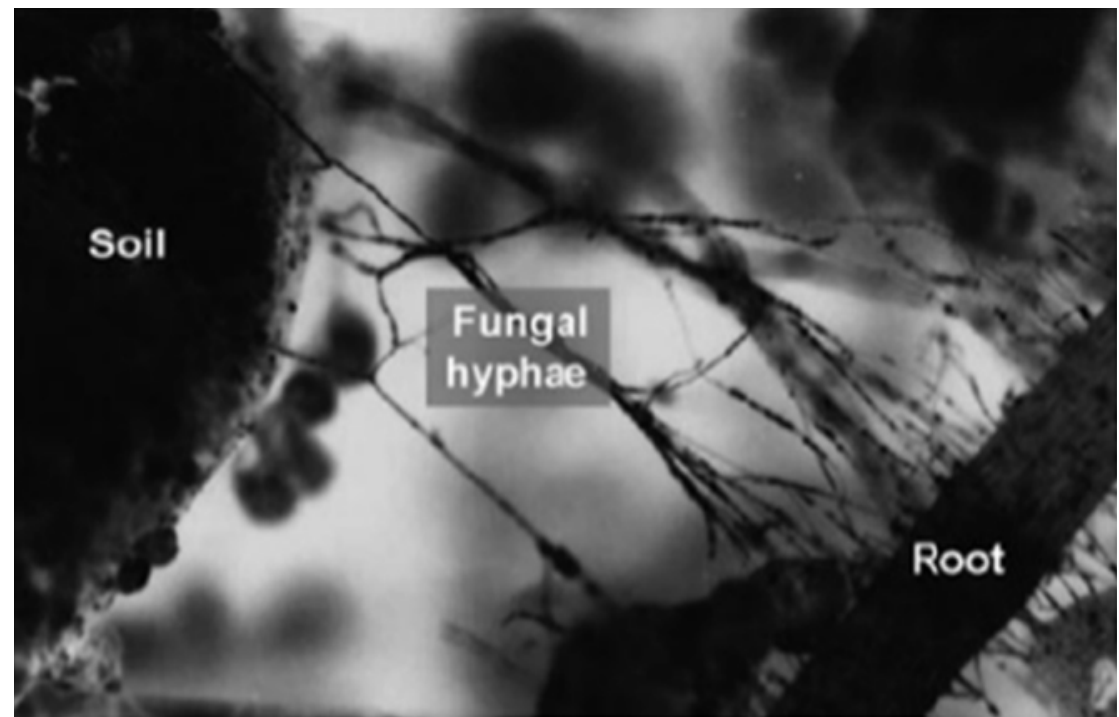

Figure 4 Mycorrhizal fungi filaments (hyphae) which enhance soil aggregation and play an important role in soil structure development Source: Al-Karaki, 2013

Glomus intraradices. In this case, the concentration of polyamines in the roots was also measurably reduced (Baum, El-Tohamy and Gruda, 2015). Hildebrandt, Regvar and Bothe (2007) demonstrated the buffering effect of mycorrhizal colonization on pea and barrelclover plants under stress from Cd.

\section{Cold}

The impact of mycorrhiza on cold stress is the subject of many scientific studies. For non-AM plants there have been observed a decrease in photosynthetic activity due to the stress, but for AM plants the same photosynthetic activity proved no stress conditions. They conclude that in mycorrhizal plants the photosynthetic apparatus was less damaged due to stress, which also affects the tolerance of the plant. Oxidation of membrane lipids is a reliable indicator of uncontrolled production of free radicals, and thus oxidative stress. In case of plants without mycorrhiza, this oxidation was higher. For mycorrhizal plants, MDA content has increased only minimally or not at all. As a result, antioxidant protection was higher in AM plants than in non-AM. It indicated that vaccination with $A M$ fungi results in a well-established defense mechanism against cold, and that the alleviation of oxidative stress can be an essential part of the real effect of symbiosis (Pedranzani et al., 2015).

\section{Physical properties of the soil}

AM fungi are considered as key determinants of soil quality. They develop an extensive network of external fungal filaments (hyphae) that act as an extension of the root absorbing area. Furthermore, AM fungi may play a role in the formation of stable soil aggregates, building up a macroporous structure of soil that allows penetration of water and air and prevents erosion, but also through elimination of sticky substances, such as the glycoprotein - glomalin, which bonds the soil particles into microaggregates, and then to more stable ones. As a result, inoculations of disturbed areas with mycorrhizal fungi could have a dual benefit: helping naturally indigenous or cultivated plants and improving soil stability macroaggregates (Figure 4) (Al-Karaki, 2013; Vogelsang et al., 2004).

\section{The importance of mycorrhizal fungi against biotic factors}

In addition to causing non-target effects, chemical pesticides are becoming more expensive year after year, loosing their effectiveness as a result of co-evolution and development of resistance to pathogens. Most of the new generation pesticides are systemic in their mode of action and leading to certain level of toxicity in the plant system and thus hazardous to health. Furthermore, they disturb the ecology of the microbial diversity in ecosystem and thus the whole environment. Therefore, many scientists have been currently working to find various alternative forms of vegetable protection against pests and pathogens. One of these, and not poorly observed, is mycorrhizal protection. Mycorrhiza inoculation has additional advantages as it is effective even against soil-borne pathogens, which are difficult and expensive to manage through chemical and physical treatments. Hence, mycorrhization has been proposed as an alternative for the management of soil-borne pathogens while AM fungi, such as biocontrol of plant diseases (biopesticides) are recommended by more and more experts and researchers in horticulture (Sharma et al., 2004).

Many studies have shown that AM fungi improve plant's resistance that consequently reduces incidence as well as severity of plant diseases caused by a wide range of attackers including viruses, bacteria, nematodes and fungi. Although well defined direct mechanisms are still unclear, several indirect mechanisms have been proposed by a number of researchers for increasing bioprotective ability of mycorrhizal plants (Singh and Giri, 2017).

AM fungi are known to improve plant growth and nutrient absorption and physiological responses of the host to environmental stresses resulting in more resistance or tolerance to pathogen attacks. These mycorrhizainduced compensatory processes may explain the increased tolerance of mycorrhizal and $\mathrm{P}$ fertilized plants as they can compensate for loss of root mass or function caused by pathogens, including nematodes. Thanks to the influence of AM fungi on growth, absorption area and cellular processes in the roots, plants can compensate for losses of plant root mass and its functions caused by pathogens or nematodes. It has been suggested that nematode pathogens, on the other hand, require host nutrients for reproduction and development and direct competition with AM fungi has been hypothesized as a mechanism of their inhibitors. Since AM fungi, soilborne fungal pathogens, and plant parasitic nematodes occupy similar root tissues, direct competition for 
space has been postulated as a mechanism of pathogen inhibition by AM fungi (Sharma et al., 2004).

It is also important to remember that an indigenous fungus adapted to specific edifying conditions has the ability to survive and colonize plant roots better than a non-native species under similar conditions. It also has a greater inculcation potential and competitive ability (Gopal et al., 2015).

Singh and Giri (2017) reported many cases in which the positive effect of AM fungi on different types of vegetable pathogens has been demonstrated: effect on different pathogenic fungi such as: Alternaria solani or Botrytis cinerea on tomatoes; Phytophthora capsici on pepper; Phytophthora parasitica on tomatoes; Phytophthora nicotianae on tomatoes; Phytophthora sojae on soy; Pythium ultimum on cucumbers; Rhizoctonia solani on potatoes or tomatoes; Sclerotium cepivorum on onion. In the context of bacterial diseases, they mentioned positive effects on: Pseudomonas syringae pv. glycine on soy; Ralstonia solanacearum and Stolbur phytoplasma on tomatoes. As for nematodes, the following was presented: Heterodera glycines on soy; Meloidogyne hapla on tomatoes; Nacobbus aberrans and Rotylenchulus reniformis on tomatoes; but especially many Meloidogyne incognita studies on tomatoes.

Additionally, the magnitude of the AM-induced decline in disease severity/nematode suppression ranged from 30 to $42 \%$ and $44-57 \%$ for fungal and nematode pathogens respectively, irrespective of pathogens' identity or lifestyle suggesting that through AM fungi, plants possibly receive similar protection from all pathogens rendering $A M$ formulations a potentially broadly effective biocontrol agent (Singh and Giri, 2017).

A suitable example would also be asparagus inoculated with AM fungi producing more shoots, and more dry matter in shoots and roots. Moreover, six weeks after the artificial infection of plants with Fusarium, root rot symptoms were manifested by only $20 \%$ of seedlings inoculated with Glomus sp. R10, while for non-AM plants, the symptoms were shown in up to $90 \%$ of plants. Similar experiments were made with pre-planted cucumber seedlings or roots of carrots, in which mycorrhiza fungi limited pathogen growth only to the outer bark of the roots (Sharma et al., 2004).

\section{Conclusions}

Recently, the use of mycorrhiza in vegetable production is addressed by many scientists, while there is also a gradually growing interest of farmers in practice. It can be concluded that inoculation of vegetables with arbuscular mycorrhizal fungi is a cultivation technique, which, when properly used, can protect plants against adverse abiotic factors, especially stress from drought, cold, salt soils, etc., but they also contribute to the protection of plants against various soil pathogens (bacteria, nematodes or insect pests). However, arbuscular mycorrhizal fungi also have a positive effect on physical properties of soil and its overall fertility, thus improving the conditions for growing the vegetables themselves. The use of AM as biopesticides has not only an impact on plant health, but also indirectly on the protection of the environment and our health as it reduces the need for harmful chemical pesticides. However, in order for the mycorrhiza itself to occur, it is necessary to know where and under what conditions we can apply the inoculum.

\section{Acknowledgement}

This study was supported by Slovak Grant Agency VEGA, No. $1 / 0087 / 17$

\section{References}

AL-KARAKI, G. 2013. The role of mycorrhiza in the reclamation of degraded lands in arid environments. In Developments in Soil Classifi cation, Land Use Planning and Policy Implications. vol. 48, 2013, pp. 823-836. ISBN 978-94-007-5331-0. [online], cit. [2018-0910]. doi: $10.1007 / 978-94-007-5332-7 \_48$

BAUM, C. - EL-TOHAMY, W. - GRUDA, N. 2015. Increasing the productivity and product quality of vegetable crops using arbuscular mycorrhizal fungi: A review. In Scientia Horticulturae. vol. 187, 2015, pp. 131-141. [online], cit. [2018-09-10]. doi: https:// doi.org/10.1016/j.scienta.2015.03.002

BETHLENFALVAY, G. J. - LINDERMAN, G. 1992. Mycorrhizae in Sustainable Agriculture. Published by American Society of Agronomy, Crop Science Society of America, and Soil Science Society of America, 1992. ISBN 978-0-89118-320-4

CANDIDO, V. - CAMPANELLI, G. - D'ADDABBO, T. - CASTRONUOVO, D. - PERNIOLA, M. - CAMELE, I. 2015. Growth and yield promoting effect of artificial mycorrhization on field tomato at different irrigation regimes. In Scientia Horticulturae, vol. 187, 2015, pp. 3543. [online], cit. [2018-09-10]. DOI: 10.1016/j.scienta.2015.02.033

DAVIES, F. T. 2016. Mycorrhizal Effects on Host Plant Physiology. Dept. Horticulture Sci., Texas A\&M University. [online], cit. [201809-10]. Available at: http://aggie-horticulture.tamu.edu/faculty/ davies/research/mycorrhizae.html

ELBON, A. - WHALEN, J. K. 2015. Phosphorus supply to vegetable crops from arbuscular mycorrhizal fungi: a review. In Biological Agriculture and Horticulture. vol. 31, 2015, no. 2, pp. 73-90. [online], cit. [2018-09-10]. DOI: https://doi.org/10.1080/01448765.2014.966 147

EL-SARKASSY, N. M. - IBRAHIM S. A. - DESOKY E. M. et al. 2017. Salinity stress amelioration using humic acid and mycorrhizae on pepper plants. In Agricultural Botany. vol. 44, 2017, no. 6B, pp. 2515-2527.

FINLAY, R. D. 2008. Ecological aspects of mycorrhizal symbiosis: with special emphasis on the functional diversity of interactions involving the extraradical mycelium. In Journal of Experimental Botany, vol. 59, 2008, no. 5, pp. 1115 - 1126. [online]. cit. [2018-0910]. DOI: https://doi.org/10.1093/jxb/ern059

GOPAL, K.S. - NANDAKUMAR, A. - MATHEW, S.K. 2010. Consortia of arbuscular mycorrhizal fungi for the management of bacterial wilt disease in susceptible tomato. In Veg. Sci., vol. 37, 2010, no. 2, pp. 205-207. Available at: https://www.researchgate.net/ publication/279750619

GRYNDLER, M. et al. 2004. Mykorhizní symbióza: o soužití hub s kořeny rostlin. Praha : Academia, 2004, 366 s. ISBN 80-200-1240-0. HABTE, M. 2000. Mycorrhizal Fungi and Plant Nutrition. In James A. Silva, J. A - Uchida, R. S. Plant Nutrient Management in Hawaii's Soils. Manoa : University of Hawaii at Manoa, 2000, pp. 127-131. ISBN 1-929235-08-8, [online] cit. [2018-09-10] Available et: http:// www.ctahr.hawaii.edu/oc/freepubs/pdf/pnm14.pdf

HAZZOUMI, Z. - MOUSTAKIME, Y. - ELHARCHLI, E. - JOUTEIET K. A. 2015. Effect of arbuscular mycorrhizal fungi (AMF) and water stress on growth, phenolic compounds, glandular hairs, and yield of essential oil in basil (Ocimum gratissimum L). In Chemical and Biological Technologies in Agriculture. vol. 2, 2015, no. 10, pp. 1-11. [online]. cit. [2018-09-10]. DOI: 10.1186/s40538-015-0035-3

HEIKHAM, E. - RUPAM, K. - BHOOPANDER, G. 2009. Arbuscular mycorrhizal fungi in alleviation of salt stress: a review. In Annals 
of Botany, vol. 104, 2009, no. 7, pp. 1263-1280. ISSN 0305-7364. [online]. cit. [2018-09-10]. DOI: https://doi.org/10.1093/aob/ mcp251

HILDEBRANDT, U. - REGVAR, M. - BOTHE, H. 2007. Arbuscular mycorrhiza and heavy metal tolerance. In Phytochemistry, vol. 68, 2007, pp. 139-146. [online], cit. [2018-09-10]. Available at: http:// www.bashanhoundation.org/bothe/botheheavymetal.pdf

KAVKOVÁ, M. 2014. Mykorizní symbióza. In Zahradnictví, roč. 33, 2014, č. 3, s. 58-60. ISSN 1213-7596.

KOIDE, R.T. - MOSSE, B. 2004. A history of research on arbuscular mycorrhiza. In Micorrhiza, vol. 14, no. 3, pp. 145-163. ISSN 09406360, [online], cit. [2018-09-10]. DOI: https://doi.org/10.1007/ s00572-004-0307-4 \t „_blank“ 10.1007/s00572-004-0307-4

MEJSTŘíK, V. 1988. Mykorrhizní symbiózy (Study report). 1. vyd., Praha : Academia, 1988, 152 s. ISBN 21-030-88.

MOHSEN, K. H. E. - ABDEL-RAHMAN, S. 2016. Alleviating salt stress in tomato inoculated with mycorrhizae: photosynthetic performance and enzymatic antioxidants. In Taibah University for Science Journal, vol. 11, 2015, no. 6, pp. 850-860. cit. [2018-09-10]. DOI: http://dx.doi.org/doi:10.1016/j.jtusci.2017.02.002

PEDRANZANI, H. - TAVECCHIO, N., M. - GUTIÉRREZ, M. - GARBERO, M. - PORCEL, R. - RUIZ-LOZAN, J. M. 2015. Differential Effects of Cold Stress on the Antioxidant Response of Mycorrhizal and NonMycorrhizal Jatropha curcas (L.) Plants. In Jurnal of Agricultural Science, vol. 7, 2015, no. 8, pp. 1916-9760. ISSN 1916-9752. [online], cit. [2018-09-10]. DOI: http://dx.doi.org/10.5539/jas.v7n8pxx

RAPPARINI, F. - PEÑUELAS, J. 2014. Mycorrhizal Fungi to Alleviate Drought Stress on Plant Growth. In Miransari M. Use of Microbes for the Alleviation of Soil Stresses, vol. 1, 2014, pp. 21-42. [online], cit. [2018-09-10]. DOI: https://doi.org/10.1007/978-1-4614-9466-9_2

ROB, H. 1985. Nové poznatky u využití mykorhizy u polních plodin. Praha : Ústav vědeckotechnických informací pro zemědělství, $1985,52 \mathrm{~s}$

SEGUEL, A. 2014. The potential of arbuscular mycorrhiza in the development of agriculture in arid and semi-arid zones. In IDESIA vol. 31, 2014, pp. 3-8. [online], cit. [2018-09-10]. DOI: 10.13140/ RG.2.1.4464.7525
SHARMA, M. P. - GAUR, A. - TANU - SHARMA, O. P. 2004. Prospects of Arbuscular Mycorrhiza in Sustainable Management of Root- and Soil-Borne Diseases of Vegetable Crops. In Fruit and Vegetable Diseases, vol. 1, 2004, pp. 501-539. DOI: 10.1007/0-306-48575-3_13 SINGH, I. - GIRI, B. 2017. Arbuscular Mycorrhiza Mediated Control of Plant Pathogens. In Mycorrhiza - Nutrient Uptake, Biocontrol, Ecorestoration, 2017, pp.131-161.ISBN 978-3-319-68867-1. [online]. cit. [2018-09-10]. DOI: https://doi.org/10.1007/978-3-319-68867-1

TAUSCHKE, M. - BEHRENDT, A. - MONK, J. - LENTZSCH, P. EULENSTEIN, F. - MONK, S. 2015. Improving the water use efficiency of crop plants by application of mycorrhizal fungi. [online], cit. [2018-09-10]. Available at: http://www.researchgate.net/ publication/275270200

TISSERANT, E. - KOHLER, A. - DOZOLME-SEDDAS, P. - BALESTRINY, R. - BENABDELAH, K. - COLARD, A. et al. 2012. The transcriptome of the arbuscular mycorrhizal fungus Glomus intraradices (DAOM 197198) reveals functional tradeoffs in an obligate symbiont. In New Phytologist, vol. 193, 2012, no. 3, pp. 755-769. [online]. cit. [201809-10]. DOI: https://doi.org/10.1111/j.1469-8137.2011.03948.x

VOGELSANG, K. M - BEVER, J. D. - GRISWOLD, M. - SCHULTZ, P. A. 2004. The Use of Mycorrhizal Fungi in Erosion Control Applications. 150s. California Department of Transportation, Sacramento, CA USA. [online], cit. [2018-09-10]. Available at: http://www.dot.ca.gov/ hq/LandArch/16_la_design/research/docs/final_report_65A070. pdf

WU, Q. S. - ZOU, Y. N. 2017. Arbuscular Mycorrhizal Fungi and Tolerance of Drought Stress in Plants. 2017. In Biomedical and Life Sciences, 2017. ISBN 978-981-10-4115-0. [online], cit. [2018-09-10]. DOI: https://doi.org/10.1007/978-981-10-4115-0_2 